\title{
Spatial variation of Zostera tasmanica morphology and structure across an environmental gradient
}

\author{
Cameron J. Miller ${ }^{1,3, *}$, Stuart J. Campbel1 ${ }^{1,2}$, Sonia Scudds ${ }^{1,4}$ \\ ${ }^{1}$ Marine Sciences, Environment Protection Authority, Victoria, Centre for Environmental Sciences, Ernest Jones Drive, \\ Macleod, Victoria 3085, Australia \\ ${ }^{2}$ Wildlife Conservation Society, Asia-Pacific Marine Program, PO Box 311, Bogor 16151, West Java, Indonesia \\ ${ }^{3}$ Present address: National Parks Division, Parks Victoria, Level 10, 535 Bourke St, Melbourne, Victoria 3000, Australia \\ ${ }^{4}$ Present address: Department of Primary Industries, 30 Prospect Street, Box Hill, Victoria 3128, Australia
}

\begin{abstract}
Spatial variation in morphological and structural characteristics of the seagrass Zostera tasmanica was examined in Westernport, an estuarine embayment in south-eastern Australia. An environmental gradient exists within the embayment, with moderate sediment loads and resuspension in the north correlating with high turbidity, chlorophyll a and reduced photon flux density (PFD). This gradient generally decreases towards the south, where oceanic influences and lower catchment inputs result in less turbid waters, with increased PFD and reduced water column chlorophyll a. We investigated variation in Z. tasmanica characteristics across this environmental gradient. A hierarchy of scales was examined ranging from $\mathrm{cm}$ within sites (meadows), $\mathrm{km}$ between sites, and $10 \mathrm{~s}$ of $\mathrm{km}$ between regions. Structural variables examined included shoot density, seagrass cover and biomass, while morphological variables were number of leaves, leaf and total shoot weight, number of nodes, internode length and shoot length. Plants from northern regions of Westernport were characterised by low leaf numbers, low shoot weight and few internodes, suggesting either a loss of condition in these plants or younger plants with high shoot turnover. In contrast, plants from the mid to southern regions had more and longer leaves, more nodes and greater internode lengths, and structurally these meadows exhibited greater densities, cover and biomass. Partitioning of the variation showed that region (>20 km apart) contributed the greatest percentage of variation for a number of variables (e.g. shoot numbers, numbers of nodes, internode length and seagrass cover), suggesting the importance of the environmental gradient in shaping seagrass form and meadow structure. These variables are potentially useful indicators of anthropogenic influences driving seagrass morphology and structure at ecosystem scales.
\end{abstract}

KEY WORDS: Zostera tasmanica $\cdot$ Seagrass $\cdot$ Spatial scale patterns $\cdot$ Morphology $\cdot$ Structure $\cdot$ Water quality · Westernport

Resale or republication not permitted without written consent of the publisher

\section{INTRODUCTION}

Anthropogenic disturbance, including turbidity and sedimentation, represents a significant threat to intertidal seagrass meadows along the southern Australian coast and has led to extensive loss of seagrasses in shallow coastal waters over recent decades (Bulthuis 1983a, Shepherd et al. 1989). Seagrass loss is of concern because of the associated loss of productivity, ecological integrity and ecosystem services. Zostera tas- manica (formerly Heterozostera tasmanica (Martens ex Asch.) den Hartog (Les et al. 2002) is considered an important indicator of ecological health within many southern Australian intertidal ecosystems, supporting a variety of marine fauna and ecosystem functions. Monitoring programs have often evaluated the health of seagrass ecosystems by monitoring sets of structural, morphological and physiological variables in conjunction with traditional water quality variables (Campbell \& Miller 2002, Kendrick et al. 2002, Balestri et al. 2003). 
An important component of effective seagrass monitoring programs is to ensure that they are based on appropriate sampling designs that account for spatial variation within and between seagrass populations (Burdick \& Kendrick 2001). Seagrasses have the capacity to modify their form and function according to environmental conditions (Erftemeijer \& Herman 1994). Heterogeneity in the physical environment can thus influence structural growth and morphology of seagrasses across a range of spatial scales (Heck \& Wetstone 1977, Duarte \& Sand-Jensen 1990, Hall et al. 1999, Balestri et al. 2003). In order to interpret the changing dynamics of seagrass distribution, data need to be collected over appropriate spatial scales (Virnstein 1995, Nakaoka \& Aioi 1999, Peterson \& Fourqurean 2001). Many studies extrapolate data from randomly collected shoots between sites, or along depth gradients (Guidetti \& Fabiano 2000, Campbell \& Miller 2002), or have focused on the variation in seagrass variables within meadows (Alcoverro et al. 1995, Marbà et al. 1996, Marbà \& Duarte 1998). Few studies have examined the natural variation in the spatial patterns of structural and morphological variables within seagrass meadows at a fixed depth (Balestri et al. 2003) and across multiple sites. Although there are many rapid and reliable methods to evaluate the expansion and decline of seagrass meadows, little guidance exists on how to design and implement cost-effective seagrass monitoring programs (Balestri et al. 2003).

Westernport is a large estuarine embayment located in southern Victoria and is subject to inputs of nutrients and suspended particulates from an agriculturally modified and urbanised catchment (Bulthuis 1983b). The seagrass Zostera tasmanica forms dense, often monospecific meadows that extend over $\mathrm{km}$-wide areas of Westernport from 0 to $10 \mathrm{~m}$ depth. During the $1970 \mathrm{~s}$ a dramatic loss of seagrass biomass $\left(\sim 45 \mathrm{~km}^{2}, \sim 85 \%\right)$ was reported in Westernport (Shapiro 1975, Bulthuis 1983b), much of this occurring on the intertidal banks and attributed to increased sedimentation and loss of light. Annual sediment inputs from the north-eastern catchment (>86200 $\mathrm{m}^{3} \mathrm{yr}^{-1}$ ) have been shown to be markedly higher than loads of sediments into other regions of the Bay (13000 $\mathrm{m}^{3} \mathrm{yr}^{-1}$ ) (Sargeant 1977) and chlorophyll $a$ and suspended sediment concentrations have increased in the north-eastern regions of Westernport during the past $25 \mathrm{yr}$ (Longmore 1997). The consequent decline in light availability in the northeastern region of the bay has caused large variations in structural and morphological characteristics of Z. tasmanica (e.g. leaf weight shoot ${ }^{-1}$ ) across $\mathrm{km}$-wide areas (Campbell \& Miller 2002). Changes in structural and morphological variables in surviving seagrass populations are likely to be photo-adaptive responses to poor habitat quality that promote resilience in seagrass pop- ulations. In addition to broad-scale environmental variation $Z$. tasmanica meadows are also exposed to smallscale environmental variation in depth, topography, substrate type, resource availability (light, nutrients) and biological and physical disturbances. Incorrect interpretation of small-scale variation may lead to an increase in Type II errors and undermine the utility of seagrass as an environmental indicator.

In this study we used a hierarchical sampling design to examine patterns of variability of intertidal Zostera tasmanica meadows in Westernport by exploring the variability of a number of commonly used structural and morphological variables over a range of scales from centimetres (between plants) to kilometres (between meadows). Regions were chosen to represent the gradient in water quality across the estuary where concentrations of suspended matter and chlorophyll a are highest in the northern region of the Bay, moderate in the central region and low in the southern region of Westernport (Campbell \& Miller 2002). Given these conditions, photon flux density (PFD) was greatest in the southern region, moderate in the central region and lowest in the northern regions of Westernport (Campbell et al. 2003). This study was designed to investigate spatial heterogeneity of a range of functional characteristics of $Z$. tasmanica (morphological and structural) as environmental indicators of the abiotic processes operating across an estuarine embayment. By measuring the relationships between physico-chemical variables and the spatial variation in seagrass characteristics, we can improve our understanding of the threshold limits of seagrass survival (Abal \& Dennison 1996, Sfriso \& Ghetti 1998, Tomasko \& Hall 1999) and explore the usefulness of using seagrasses as indicators of water quality over a range of spatial scales.

\section{MATERIALS AND METHODS}

Study site. Westernport is a large estuarine embayment $\left(680 \mathrm{~km}^{2}\right)$ in south-eastern Australia, and comprises extensive intertidal mudflats, fringed by mangroves and saltmarshes (Fig. 1). Deep natural channels $(>20 \mathrm{~m}$ ) form the North Arm and East Arm channels which act as the major tidal exchange channels. Sea surface temperatures range from $\sim 10^{\circ} \mathrm{C}$ in winter to $\sim 22^{\circ} \mathrm{C}$ in summer, and annual salinities range from 32 to 38 PSU (EPA 1996). Spatial variation in salinity between regions is minimal due to significant tidal flushing and the relatively low volume of freshwater inputs from surrounding catchments.

Large meadows of Zostera tasmanica occur on intertidal mud banks throughout Westernport. Three broad regions of Westernport were selected for this study: the Upper North Arm (UNA), the Lower North Arm (LNA) 


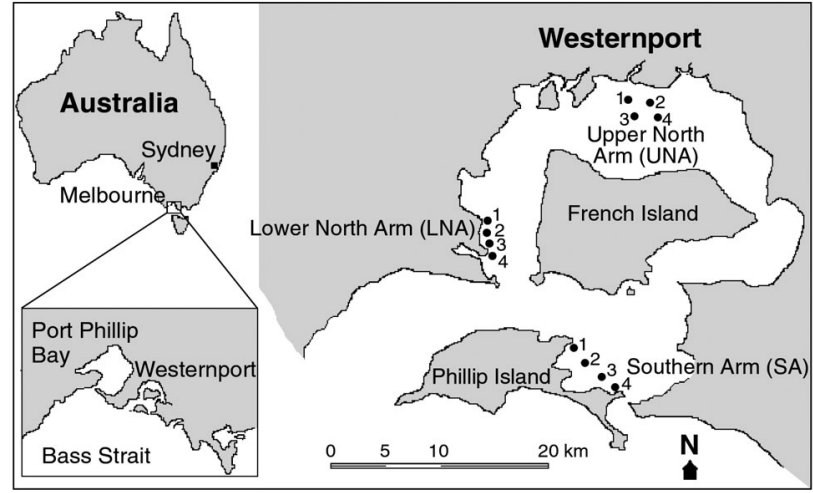

Fig. 1. Map of Westernport showing locations of Sites 1 to 4 within each of 3 regions, Southern Arm (SA), Lower North Arm (LNA) and Upper North Arm (UNA)

and the Southern Arm (SA) (Fig. 1). These regions were selected because of their similarity in physical traits such as exposure to wave action, stability and height of mudflats, topographic uniformity and our knowledge of $Z$.tasmanica variation across them. Each region is exposed at low tide for approximately equal periods of time ( 2 to $3 \mathrm{~h}$ ) per cycle with comparable tidal ranges.

Water column variables. Water column variables were recorded at the 3 regions each month from March 1998 to March 1999 (September 1998 data not available due to poor weather) using standard protocols (APHA 1995). For suspended matter $\left(\mathrm{mg} \mathrm{l}^{-1}\right)$, chlorophyll a $(\mu \mathrm{g}$ $\mathrm{l}^{-1}$ ) and inorganic nutrients (ammonium-N, nitrate-N and phosphate-P, $\mu g \mathrm{l}^{-1}$ ) water was filtered through Whatman GF/F filters and placed in a pre-rinsed, acidwashed $150 \mathrm{ml}$ polyethylene WhirlPak ${ }^{\mathrm{TM}}$ and placed on ice. Chlorophyll a was determined by filtering in situ 11 of water through Whatman GF/F filters, which were immediately placed in foil packets and cooled on ice. Chlorophyll was then extracted by acetone extraction according to methods of APHA (1998) and Parsons et al. (1989). Suspended matter and nutrients were measured in water collected in pre-rinsed bottles in situ and stored on ice. In the laboratory total suspended solids were analysed using the gravimetric method (APHA 1995). Nutrient samples were analysed in a segmented flow analyser (Technicon ${ }^{\mathrm{TM}}$ ) for $\mathrm{N}$ as $\mathrm{NH}_{4}{ }^{+}$and $\mathrm{NO}_{3}{ }^{+}$ and $\mathrm{P}_{\text {as }} \mathrm{PO}_{4}{ }^{3-}\left(\mu \mathrm{g} \mathrm{l}^{-1}\right)$ using standard protocols (APHA 1995). Salinity (PPS) was measured in situ using a salinity meter (Model 33, Yellow Springs).

Experimental design. In January 1999 we used a nested sampling design to examine the variation in seagrass characteristics across different spatial scales in Westernport, including small plots $\left(0.25 \mathrm{~m}^{2}\right)$, sites $\left(2500 \mathrm{~m}^{2}\right)$, and regions $\left(5 \mathrm{~km}^{2}\right)$. Three regions (fixed) were chosen encompassing approximately $5 \mathrm{~km}^{2}$ of seagrass habitat, separated at a distance of $>20 \mathrm{~km}$. Within each region, 4 sites $(50 \times 50 \mathrm{~m})$ were randomly selected, separated by a distance of approximately $2 \mathrm{~km}$ (Fig. 1). Within each site, 10 plots $(50 \times 50 \mathrm{~cm})$ were randomly sampled. For the structural variables shoot density and seagrass cover, plot was the lowest unit of replication. In addition, 10 vertical shoots were harvested from within each plot and transported at ambient temperature to the laboratory to measure shoot morphological variables.

Spatial variation in structural and morphological characteristics. For each seagrass shoot the number of leaves, vertical shoot length, leaf weight shoot ${ }^{-1}$ and total weight shoot $^{-1}$ were measured according to the methods of Bulthuis (1982). Internode length (IL) and number of nodes were also measured for each plant such as described in Marbà \& Walker (1999). Seagrass cover $(\%)$ estimates were determined by randomly placing a quadrat $(50 \times 50 \mathrm{~cm}$ with cross-hairs at $10 \mathrm{~cm}$ intervals) over the seagrass and counting the number of times seagrass occurred under cross-hair intersections. A core $\left(0.025 \mathrm{~m}^{2}\right)$ was then harvested from within each plot in an area where shoots had not been harvested. For each core, shoot density (shoots $\mathrm{m}^{-2}$ ) was calculated and seagrass material dried overnight at $70^{\circ} \mathrm{C}$ in order to calculate leaf, stem and total (stem + leaf) biomass ( $g$ dry wt $\mathrm{m}^{-2}$ ).

Data analysis. Water quality data was pooled over all months for analysis ( $\mathrm{n}=11$ to 12 ) and an analysis of variance (ANOVA) used to test for significant effect of regions.

We used a 2-way nested ANOVA to examine the effects of region (fixed) and site (random) on shoot density ( shoots $\mathrm{m}^{-2}$ ), biomass measures $\left(\mathrm{g}\right.$ dry $\mathrm{wt} \mathrm{m}^{-2}$ ) and seagrass cover (\%). Cover estimates were arcsinesquare-root-transformed before analysis. A 3-way nested ANOVA was used to examine the effects of region (fixed), site (random) and plot (random) on morphological variables (number of leaves, vertical shoot length, leaf weight shoot ${ }^{-1}$, total weight shoot ${ }^{-1}$, number of nodes, and IL). Variance components for both analyses were partitioned and expressed as the proportion of variation explained by each factor based on Eq. (1). Significance amongst groups was examined using a posteriori Bonferroni tests ( $\mathrm{p}<0.05)$.

$$
100 \times \frac{\text { factor sum of squares }}{\text { total sum of squares }}
$$

\section{RESULTS}

\section{Water quality variables}

Suspended matter $\left(\mathrm{mg} \mathrm{l}^{-1}\right)$ and chlorophyll a $\left(\mu \mathrm{g} \mathrm{l}^{-1}\right)$ varied significantly between regions with higher concentrations of both variables at UNA than LNA and SA (Table 1). Significantly higher ammonium-N ( $\left.\mu \mathrm{g} \mathrm{l}^{-1}\right)$ 
Table 1. Mean $( \pm$ SE) water quality variables for 3 regions in Westernport. For each variable different letters represent significant effect (ANOVA, $\mathrm{p}<0.05$ ) of region

\begin{tabular}{|lcccccc|}
\hline Region & $\begin{array}{c}\text { Suspended matter } \\
\left(\mathrm{mg} \mathrm{l}^{-1}\right) \\
\mathrm{n}=36\end{array}$ & $\begin{array}{c}\text { Chlorophyll } \mathrm{a} \\
\left(\mu \mathrm{l} \mathrm{l}^{-1}\right) \\
\mathrm{n}=36\end{array}$ & $\begin{array}{c}\text { Salinity } \\
(\mathrm{PPS}) \\
\mathrm{n}=12\end{array}$ & $\begin{array}{c}\text { Ammonium-N } \\
\left(\mu \mathrm{g} \mathrm{l}^{-1}\right) \\
\mathrm{n}=12\end{array}$ & $\begin{array}{c}\text { Nitrate-N } \\
\left(\mu \mathrm{l}^{-1}\right) \\
\mathrm{n}=12\end{array}$ & $\begin{array}{c}\text { Phosphate-P } \\
\left(\mu \mathrm{I} \mathrm{l}^{-1}\right) \\
\mathrm{n}=12\end{array}$ \\
\hline UNA & $20.76(1.85) \mathrm{a}$ & $2.63(0.22) \mathrm{a}$ & $32.5(0.34) \mathrm{a}$ & $7.34(0.98) \mathrm{a}$ & $3.57(0.97) \mathrm{a}$ & $6.13(0.66) \mathrm{ab}$ \\
LNA & $7.87(0.36) \mathrm{b}$ & $1.75(0.14) \mathrm{b}$ & $33.3(0.39) \mathrm{ab}$ & $6.53(0.73) \mathrm{ab}$ & $3.86(1.01) \mathrm{a}$ & $7.73(0.65) \mathrm{a}$ \\
$\mathrm{SA}$ & $6.14(0.35) \mathrm{b}$ & $1.26(0.14) \mathrm{c}$ & $33.9(0.29) \mathrm{b}$ & $4.67(0.41) \mathrm{b}$ & $1.98(0.65) \mathrm{a}$ & $5.12(0.46) \mathrm{b}$ \\
\hline
\end{tabular}
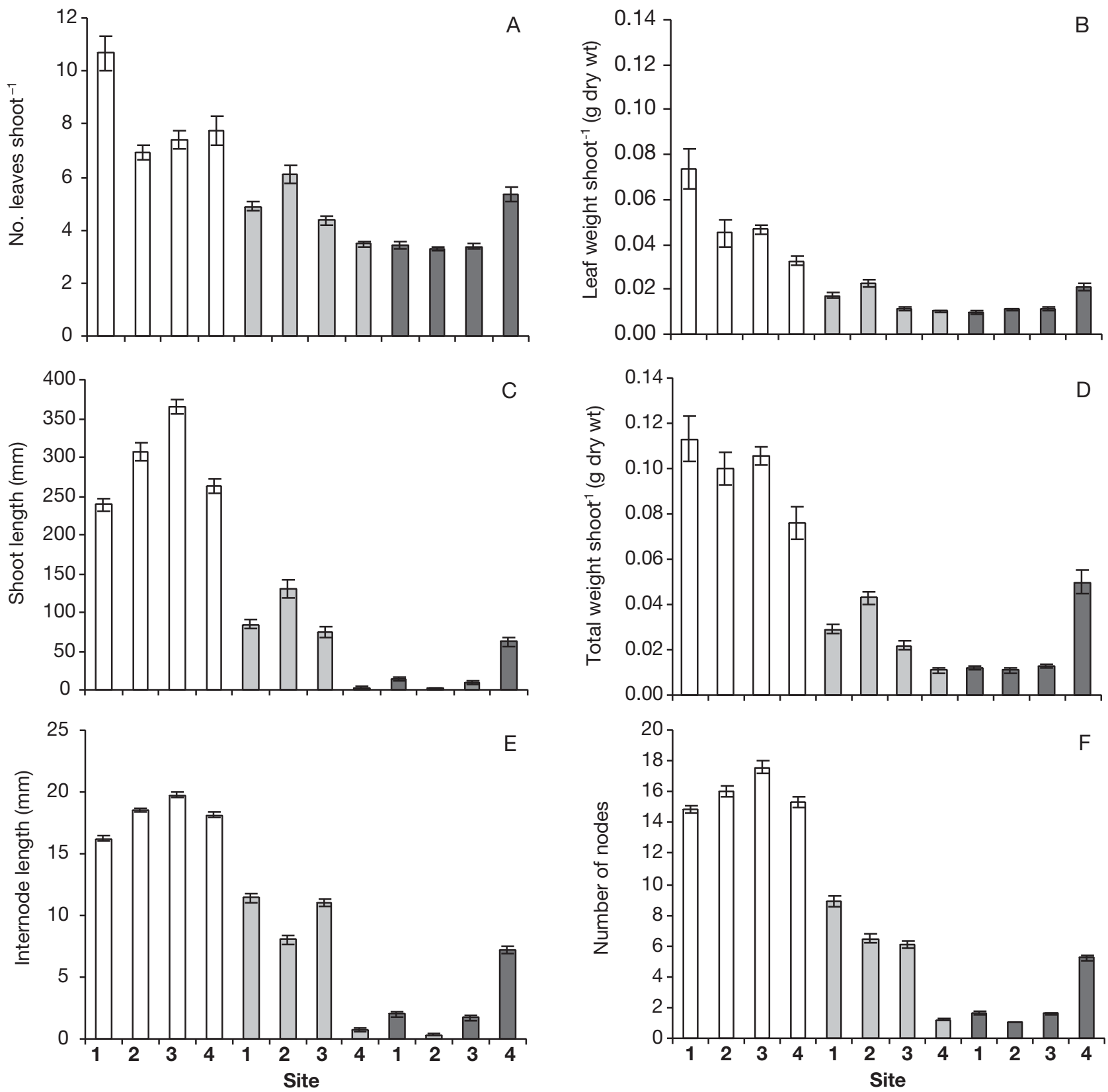

Fig. 2. Zostera tasmanica. Mean $( \pm$ SE) morphological characteristics at 4 sites within each region: ( $\square$ ) Southern Arm (SA) ( $\square$ ) Lower North Arm (LNA) and ( $\square$ ) Upper North Arm (UNA). (A) number of leaves shoot ${ }^{-1}$, (B) leaf weight shoot ${ }^{-1}$, (C) shoot length, (D) total weight shoot ${ }^{-1}(\mathrm{E})$, internode length shoot ${ }^{-1},(\mathrm{~F})$ number of nodes shoot ${ }^{-1}$ 
and phosphate-P ( $\mu \mathrm{g}^{-1}$ ) and lower salinity (PPS) were found at UNA compared with the SA (Table 1). No difference in nitrate-N ( $\left.\mu \mathrm{g} \mathrm{l}^{-1}\right)$ was found between regions.

\section{Seagrass morphological variables}

Values for measures of shoot morphological variables (no. leaves, shoot length, leaf weight and total shoot weight) averaged across sites within regions were 1.5 to 13 times greater at SA compared to LNA and UNA (Fig. 2A-D) with the greatest difference observed in shoot length. At UNA, average shoot length ( \pm standard error) was $21.9 \mathrm{~mm}( \pm 13)$, while at LNA and SA lengths were $72.0 \mathrm{~mm}( \pm 26)$ and $293.6 \mathrm{~mm}$ $( \pm 27)$, respectively. Plants in the SA had approximately double the number of leaves $(8.15 \pm 0.8)$ than plants from LNA $(4.7 \pm 0.5)$ and UNA $(3.9 \pm 0.8)$. This pattern was also evident for nodal variables (Fig. 2E,F). Plants within SA had an average of $15.9( \pm 0.343)$ nodes while those in LNA had $7.8( \pm 0.289)$ with $2.8( \pm 0.148)$ in
UNA. Vertical IL ranged from 7 to $22 \mathrm{~mm}$ (Fig. 2E) and showed significant regional differences as with other variables. Mean IL recorded at SA was $18.2 \mathrm{~mm}$ $( \pm 0.202), 7.8 \mathrm{~mm}( \pm 0.360)$ at LNA and $2.8 \mathrm{~mm}( \pm 0.258)$ in UNA. At the regional scale all morphological variables demonstrated declining seagrass condition in a northerly direction from SA to UNA. Plants in the southern region are clearly in better condition: they have more abundant leaves that are longer, longer shoots, more growth nodes and longer IL, and have greater leaf and total plant weights.

\section{Seagrass structural variables}

The pattern of declining seagrass condition from south to north was also reflected in aspects of plant structure. Shoot density was found to be highest at SA $\left(1650 \pm 244\right.$ shoots $\left.\mathrm{m}^{-2}\right)$, intermediate at LNA (1108 \pm 436 shoots $\left.\mathrm{m}^{-2}\right)$, and low at UNA $\left(601 \pm 129\right.$ shoots $\left.\mathrm{m}^{-2}\right)$ (Fig. 3A). As would be expected, seagrass cover was lowest at UNA $(40.3 \pm 7.3 \%)$, intermediate at LNA
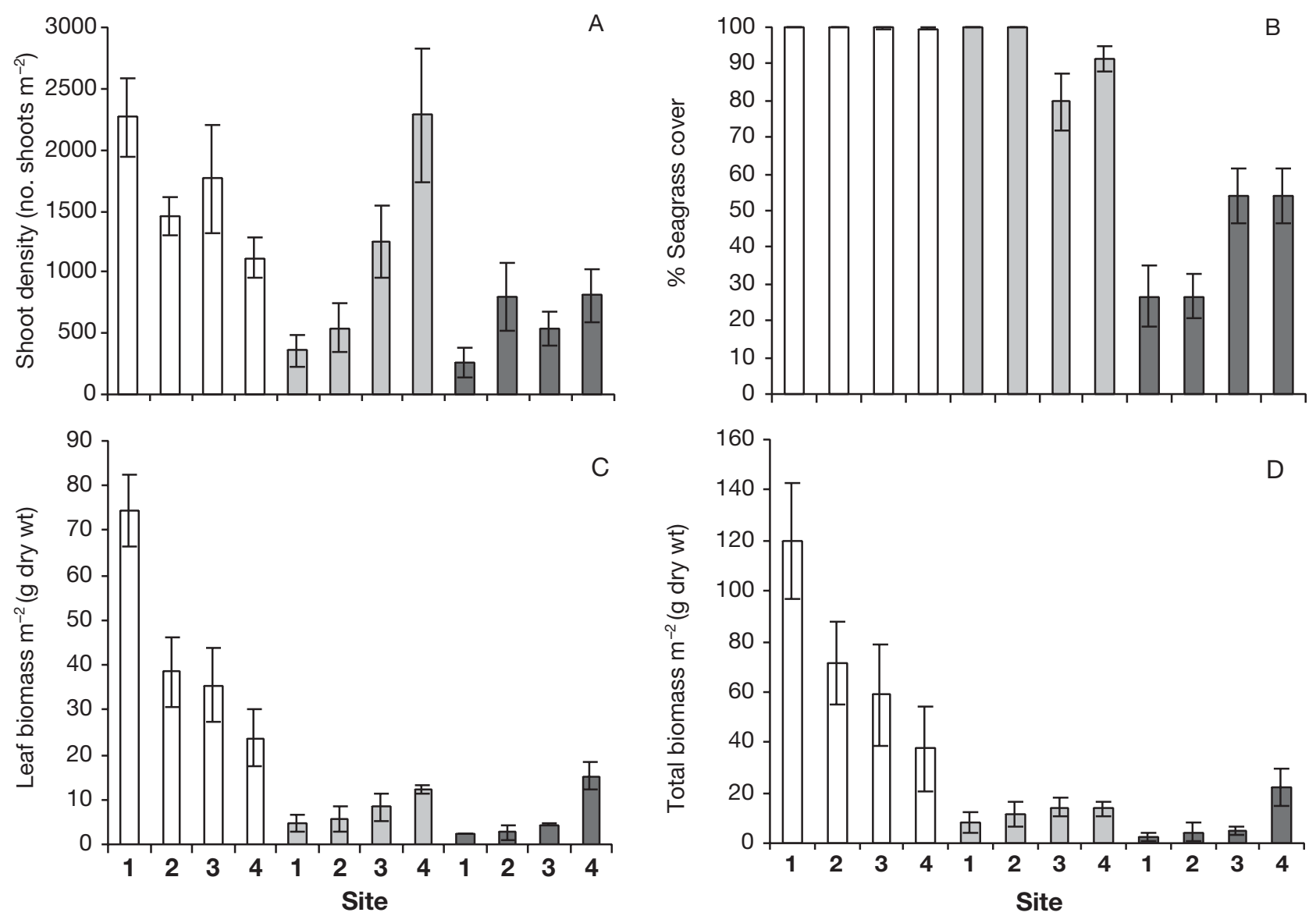

Fig. 3. Zostera tasmanica. Mean $( \pm$ SE) structural characteristics at 4 sites within each region: $(\square)$ Southern Arm (SA), ( $\square)$ Lower North Arm (LNA) and ( $\square$ ) Upper North Arm (UNA). (A) shoot density $\mathrm{m}^{-2},(\mathrm{~B}) \%$ seagrass cover, (C) leaf biomass $\mathrm{m}^{-2}$, (D) total biomass $\mathrm{m}^{-2}$ 
$(92 \pm 5.6 \%)$ and high at SA $(99.8 \pm 0.15 \%)$ (Fig. 3B) Leaf and total biomass ( $g$ dry wt $\mathrm{m}^{-2}$ ) also showed a similar pattern with low leaf and total biomass at UNA and high leaf and total biomass at SA (Fig. 3C,D).

\section{Spatial scale effects}

Figs. 2 \& 3 demonstrate the strong influence region has on seagrass morphology and meadow structure. Also notable from these figures, however, is smaller-scale heterogeneity between and within sites. Significant effects of region, site and plots were found, or all morphological variables with significant effects of region and site on structural variables. Partitioning of the variation showed that areas separated by $>20 \mathrm{~km}$ contributed the greatest percentage of variation for leaf weight $(44.4 \%)$, total shoot weight $(51.8 \%)$, shoot length $(70.4 \%)$, number of nodes $(57.5 \%)$, IL $(59.1 \%)$ (Table 2) and seagrass cover $(69.1 \%)$ (Table 3). Variation attributable to sites was $\leq 21.9 \%$ for all morphological and structural variables (Tables $2 \& 3$ ). Variation attributable to plots was generally $\leq 17 \%$ for morphological variables (Table 2). For all morphological variables except numbers of leaves shoot $^{-1}$, the percentage of unexplained variation (variation between plants) was less than regional variation but greater than site and plot variation (Table 2). In contrast, all structural variables (except seagrass cover) had greater unexplained variation (variation between plots) than site and regional variation (Table 3).

Variation across sites within each region generally showed a consistent pattern with 1 site standing out from the other 3 by having inconsistent results for most, but not all, variables. Of the 4 sites in SA, plants at Site 1 (SA 1) had the greatest number of leaves and leaf weight, whilst SA 3 had the greatest number of nodes, IL and shoot length (Fig. 2). Within LNA, LNA 4 had substantially fewer nodes than the other sites, low IL and low shoot length and leaf and total shoot weight (Fig. 2). UNA 4 was also considered an outlier, with plants and meadows at this site appearing to be morphologically and structurally more similar to LNA. Plants at UNA 4 had significantly more leaves, greater leaf and total shoot weights, shoot length, IL, and more nodes compared with other sites in UNA (Fig. 2). It is likely that these 'outlying' sites contributed most to the significant differences found between sites (Tables $2 \& 3$ ).

Of the structural variables examined, shoot density was found to be highly variable across sites
Table 2. Zostera tasmanica. Two-way nested ANOVA of shoot morphological variables. Partitioning of variation given as \% variation expressed as proportion of variation explained by each factor (region, site, plot). Leaf number shoot ${ }^{-1}$, leaf weight shoot ${ }^{-1}$ and total shoot weight shoot ${ }^{-1}$ were $\log _{\mathrm{e}}(x+1)$-transformed prior to analysis

\begin{tabular}{|c|c|c|c|c|c|}
\hline & df & MS & $F$ & $\mathrm{p}$ & $\begin{array}{c}\% \\
\text { variation }\end{array}$ \\
\hline \multicolumn{6}{|l|}{ Leaf no. shoot ${ }^{-1}$} \\
\hline Region & 2 & 50.056 & 15.041 & 0.001 & 35.4 \\
\hline Site (Region) & 9 & 3.328 & 5.208 & 0.001 & 8.1 \\
\hline Plot (Site) & 36 & 0.639 & 4.712 & 0.001 & 15.2 \\
\hline Error & 1152 & 0.136 & & & 41.2 \\
\hline \multicolumn{6}{|c|}{ Shoot length (mm) } \\
\hline Region & 2 & 8348202.060 & 38.370 & 0.001 & 70.4 \\
\hline Site (Region) & 9 & 217571.800 & 8.872 & 0.001 & 6.7 \\
\hline Plot (Site) & 36 & 24522.980 & 5.306 & 0.001 & 6.9 \\
\hline Error & 1152 & 4620.394 & & & 16.0 \\
\hline \multicolumn{6}{|c|}{ Leaf weight shoot ${ }^{-1}$ ( $g$ dry wt) } \\
\hline Region & 2 & 193.871 & 21.297 & 0.001 & 44.4 \\
\hline Site (Region) & 9 & 9.103 & 4.339 & 0.001 & 6.7 \\
\hline Plot (Site) & 36 & 2.098 & 6.175 & 0.001 & 17.0 \\
\hline Error & 1152 & 0.332 & & & 31.9 \\
\hline \multicolumn{6}{|c|}{ Total weight shoot ${ }^{-1}$ (g dry wt) } \\
\hline Region & 2 & 391.358 & 18.637 & 0.001 & 51.8 \\
\hline Site (Region) & 9 & 20.999 & 6.963 & 0.001 & 10.1 \\
\hline Plot (Site) & 36 & 3.016 & 7.144 & 0.001 & 14.5 \\
\hline Error & 1152 & 0.422 & & & 23.6 \\
\hline \multicolumn{6}{|c|}{ No. nodes shoot ${ }^{-1}$} \\
\hline Region & 2 & 20019.320 & 848.841 & 0.001 & 57.5 \\
\hline Site (Region) & 9 & 515.194 & 21.825 & 0.001 & 4.8 \\
\hline Plot (Site) & 36 & 107.170 & 4.512 & 0.001 & 9.9 \\
\hline Error & 1152 & 23.585 & & & 27.8 \\
\hline \multicolumn{6}{|c|}{ Internode length shoot ${ }^{-1}(\mathrm{~mm})$} \\
\hline Region & 2 & 24504.540 & 1226.112 & 0.001 & 59.1 \\
\hline Site (Region) & 9 & 1192.070 & 59.604 & 0.001 & 10.9 \\
\hline Plot (Site) & 36 & 115.060 & 5.762 & 0.001 & 9.6 \\
\hline Error & 1152 & 19.986 & & & 20.3 \\
\hline
\end{tabular}

Table 3. Zostera tasmanica. Nested ANOVA of shoot density percent seagrass cover, leaf biomass and total biomass in Westernport. Partitioning of variation given as \% variation expressed as proportion of variation explained by each factor (region, site)

\begin{tabular}{|c|c|c|c|c|c|}
\hline & df & MS & $F$ & $\mathrm{p}$ & $\begin{array}{c}\% \\
\text { variation }\end{array}$ \\
\hline \multicolumn{6}{|c|}{ Shoot density $\mathrm{m}^{-2}$} \\
\hline Region & 2 & 7118.408 & 13.764 & 0.002 & 14.7 \\
\hline Site (Region) & 9 & 2307.472 & 4.462 & 0.001 & 21.9 \\
\hline Error & 108 & 517.183 & & & 63.3 \\
\hline \multicolumn{6}{|c|}{ Seagrass Cover (\%) } \\
\hline Region & 2 & 31.445 & 673.170 & 0.001 & 85.7 \\
\hline Site (Region) & 9 & 0.407 & 6.003 & 0.001 & 4.0 \\
\hline Error & 108 & 0.407 & 8.476 & & 10.4 \\
\hline \multicolumn{6}{|c|}{ Leaf biomass $\mathrm{m}^{-2}$ (g dry wt) } \\
\hline Region & 2 & 17354.470 & 9.912 & 0.001 & 25.2 \\
\hline Site (Region) & 9 & 1750.895 & 3.387 & 0.001 & 8.0 \\
\hline Error & 108 & 516.834 & & & 66.8 \\
\hline \multicolumn{6}{|c|}{ Total biomass $\mathrm{m}^{-2}$ (g dry wt) } \\
\hline Region & 2 & 50983.000 & 11.678 & 0.001 & 28.0 \\
\hline Site (Region) & 9 & 4365.791 & 3.227 & 0.001 & 7.2 \\
\hline Error & 108 & 1352.916 & & & 64.8 \\
\hline
\end{tabular}


and plots (Fig. 3A, Table 3). Seagrass cover was very uniform across SA sites and plots, but was found to be patchily distributed across LNA and UNA sites and plots (Fig. 3B). Unexplained variation between plots for seagrass cover accounted for $<10.4 \%$ of the variation (Table 3). Leaf and total plant biomass also showed significant variation across sites and plots (Fig. 3C,D, Table 3).

\section{DISCUSSION}

This study is an important investigation because it tests the utility of a comprehensive range of morphological and structural 'indicators' across multiple spatial scales in an estuarine embayment. This study provides evidence that significant differences in morphological and structural characteristics of Zostera tasmanica occur at a range of spatial scales from $\mathrm{cm}$ to $10 \mathrm{~s}$ of $\mathrm{km}$. Plants from northern regions of Westernport were characterised by low leaf numbers, low shoot weights, low shoot densities and very few internodes, suggesting that these are young plants with high turnover. In contrast, plants from the mid to southern regions were found to have more and longer leaves, more nodes and longer internode lengths as well as having higher shoot densities and 2 to 4 times greater seagrass cover. Loss of seagrass condition and thinning meadow structure is a common response to chronic light stress in subtidal seagrass meadows (Dennison \& Alberte 1985, Cambridge et al. 1986, Abal \& Dennison 1996, Hall et al. 1999, Zieman et al. 1999). Our results provide evidence that the growth and structure of intertidal seagrass can also display responses characteristic of chronic light stress despite being exposed to light for up to $4 \mathrm{~h}$ per day. Under such conditions the reduction in shoot density can lead to a reduction of self shading and therefore enhance light harvesting efficiencies of the remaining plants (Hemminga \& Duarte 2000).

The high variability in shoot morphology and structural traits between populations of Zostera tasmanica at the regional scale $(>20 \mathrm{~km})$ suggests that factors influencing seagrass shoot growth and form in Westernport are influenced by processes operating at the estuary-wide scale (Campbell \& Miller 2002). Elevated sediment and nutrient enrichment of northern Westernport waters leading to low photon fluxes have been identified as major causes of reduced seagrass shoot densities and seagrass die-off in this and other ecosystems (Bulthuis 1983a, Durako 1994, Hall et al. 1999, Campbell \& Miller 2002). The pattern of high shoot weight in areas characterised by high light availability (i.e. low suspended matter) is consistent with other studies (Short \& Wyllie-Escheverria 1996, Hall et al.
1999) and suggests that photon flux is one of the primary factors responsible for intertidal seagrass meadow structure in this embayment. Inter-regional differences in photosynthetic performance of $Z$. tasmanica (Campbell et al. 2003) may, in part, explain the high variation in morphological and structural traits observed between regions. In our study a relatively minor change in salinity (32 to 35 PSU) across the regions was evident and may have some influence on $Z$. tasmanica, but is unlikely to explain the significant regional differences in morphology and structure. Long-term monitoring of salinity over the last $10 \mathrm{yr}$ in the 3 regions in Westernport has shown no temporal or spatial trends (Longmore 1997) to indicate reduced seagrass biomass and condition is caused by salinity change.

This study suggests that for most variables, the most important scales of spatial variation for Zostera tasmanica shoot morphology and structure occurred at large (inter-region, $>20 \mathrm{~km}$ ) and small (inter-plot, $<10 \mathrm{~m}$ ) spatial scales. Variables that best reflected the environmental gradient were shoot length, number of internodes, internode length, total shoot weight, cover and total biomass. At small scales seagrasses may form variable patches (Heck \& Wetstone 1977, Hall et al. 1999) because of heterogeneity in local habitat conditions such as physical disturbance, sediment type, topographic complexity (Balestri et al. 2003) and because of inter-annual variability in recruitment, growth and coalescence of plants (Duarte \& SandJensen 1990). Heterogeneity within patches of seagrass is common and has been found with other species, such as Posidonia oceania (Balestri et al. 2003) and Halophila ovalis (Nakaoka \& Aioi 1999). Withinpatch (i.e. site) variation may result from groups of seagrass shoots or individual shoots of several age cohorts (Durako 1994). This study demonstrates that significant within-site variation can occur but is generally low compared to regional and unexplained variation. The high unexplained variation for some traits (leaf number shoot ${ }^{-1}$, leaf weight shoot $^{-1}$, shoot density $\mathrm{m}^{-2}$ ) reflects high variability at small spatial scales $(<1 \mathrm{~m}$ to $10 \mathrm{~m}$ ), and suggests that greater sampling effort would be required if these variables were to be used in ongoing site-scale assessments. Unexplained variation was particularly low for shoot length (16\% total variation) and seagrass cover (10.4\% total variation) suggesting that these variables may be particularly useful for long-term monitoring studies, as reduced sampling effort would be required to meet adequate levels of precision to detect temporal trends.

The higher numbers of internodes and greater nodal lengths at SA and LNA relative to UNA suggest an abundance of older living shoots and relatively low mortality in these regions. The shorter nodal length 
and fewer internodes of UNA populations indicate these are comprised of relatively young plants with possibly low growth rates. These plants are likely to survive the negative effects of low light availability by investing energy into small shoots forming sparse meadows but having relatively rapid shoot turnover to maintain carbon balance. Below ground carbohydrate reserves are likely to be lower in these plants compared to the structurally more robust plants in southern populations and, therefore, energy reserves may largely be available for growth at the expense of reproductive effort. Such strategies would benefit populations of Zostera tasmanica that are chronically stressed due to poor water quality, allowing rapid colonisation and partially offsetting high shoot mortality rates. High turnover of $Z$. tasmanica has been reported in Western Australia (vertical stem turnover 5.8 times $\mathrm{yr}^{-1}$ ) (Marbà \& Walker 1999) where rapidly expanding monospecific fronts form morphologically heterogeneous patches (Vermaat et al. 1996, Marbà \& Walker 1999). Other fast-growing seagrass species have been found to form heterogeneous patches due to the distribution and abundance of seeds within the substrate (Inglis 2000). Similar strategies employed by $Z$. tasmanica in Westernport may contribute to small-scale patchiness observed in this study. Z. tasmanica is a short-lived and rapidly growing species, where rhizome chains last 1 to $2 \mathrm{yr}$ and populations have low rates of turnover (Duarte et al. 1994). Z. tasmanica has been found to require fewer resources to produce their modules than many longer-lived seagrass species (Vermaat et al. 1996, Marbà \& Walker 1999). They are therefore well equipped to rapidly colonise new areas through rhizome expansion or to meander through gaps in existing beds. Such a strategy may partially offset the reductions in structural biomass and condition that occur in response to poor water quality and promote resilience and survival in populations under limiting conditions such as those in the north of Westernport.

The findings of this study demonstrate the importance of replication across multiple spatial scales when elucidating the status of Zostera tasmanica meadows across large areas or embayments. The observed differences between meadows at the largest spatial scale (>20 km) are likely to reflect real spatial differences. These patterns are also likely to persist over inter-annual cycles as a concurrent study demonstrated consistent differences in population structure and shoot morphology between regions throughout an annual cycle in Westernport (Campbell \& Miller 2002). In this study, while sites ( $2 \mathrm{~km}$ apart) were found to be significantly different, this variation generally accounted for $<10 \%$ of the total variation (stem weight and shoot density being exceptions), and is likely to be driven by single anomalous sites within regions. In a hypothetical situation, if these sites were randomly sampled and data extrapolated to represent regions, then different interpretations of spatial patterns operating at the regional scale could emerge. Thus, the scale at which variables are sampled can obviously have significant ramifications on the interpretation of environmental trends.

Similarly, the selection of variables to measure can have a significant influence on the interpretation of natural or human-induced change. Those variables that exhibited large variation across the 3 regions studied (i.e. shoot length, number of internodes, internode length and total shoot weight and seagrass cover) are potential indicators of processes that influence change in seagrass landscapes at the ecosystem-wide scale generally of interest to coastal management agencies. Seagrass characteristics that show high unexplained variation are more likely to be influenced by processes or habitat traits acting at small scales such as physical disturbance, sediment type, topographic complexity, and nutrient availability. If these variables are used in broad-scale ecosystem studies, trends will be more difficult to elucidate and are likely to be confounded by such heterogeneity unless appropriate sampling effort is undertaken. When using seagrass morphological and structural characteristics as indicators of water quality, we recommend hierarchical sampling designs incorporating a number of spatial scales that allow optimisation of sampling effort across those spatial scales. Such an approach would allow efficient and cost-effective surveying of seagrass meadows which is currently required to strengthen management decisions based on seagrass status and trends.

Acknowledgements. This study was funded by the Environment Protection Authority, Victoria, and fully complies with current Commonwealth laws and regulations. Sincere thanks to D. Newton for his ongoing support of the program, A. Stephens and N. Biggins for their contributions to the fieldwork, technical knowledge and support. Water quality analyses were supplied by G. Fabris of Primary Industries Research Victoria-Marine and Freshwater Systems (PIRVIC-MFS) (formerly, the Victorian Marine and Freshwater Institute [MAFRI]). F. Gerig presented himself whenever requested. A. Steven and R. Bathgate also provided useful comments on the manuscript, which we appreciate.

\section{LITERATURE CITED}

Abal EG Dennison WC (1996) Seagrass depth range and water quality in southern Moreton Bay, Queensland, Australia. Mar Freshw Res 47:763-771

Alcoverro T, Duarte CM, Romero J (1995) Annual growth dynamics of Posidonia oceania: contribution of large-scale versus local factors to seasonality. Mar Ecol Prog Ser 120: 203-210

APHA (1998) Standard methods for the examination of water and wastewater, 20th edn. American Public Health Association, Washington, DC, p 1-55

Balestri E, Cinelli F, Lardicci C (2003) Spatial variation in 
Posidonia oceania structural, morphological and dynamic features in a northwestern Mediterranean coastal area: a multi-scale analysis. Mar Ecol Prog Ser 250:51-60

Bulthuis DA (1982) Studies on seagrass Heterozostera tasmanica in Westernport and Port Phillip Bay, Victoria, Australia. PhD thesis, La Trobe University

Bulthuis DA (1983a) A report on the status of seagrasses in Western Port in May 1983. Internal Report No. 38. Marine Science Laboratories, Ministry for Conservation, Victoria

Bulthuis DA (1983b) Effects of in situ light reduction on density and growth of the seagrass Heterozostera tasmanica (Martens ex Aschers.) den Hartog in Westernport, Victoria, Australia. J Exp Mar Biol Ecol 67:91-103

Burdick DM, Kendrick GA (2001) Standards for seagrass collection, identification and sample design. In: Short FT, Coles RG (eds) Global research methods. Elsevier, Amsterdam, p 79-99

Cambridge ML, Chiffings AW, Brittan C, Moore AJ (1986) The loss of seagrass in Cockburn Sound, Western Australia. II. Possible causes of seagrass decline. Aquat Bot 24: 269-285

Campbell SJ, Miller CJ (2002) Shoot and abundance characteristics of the seagrass Heterozostera tasmanica in Westernport estuary (south-eastern Australia). Aquat Bot 73: $33-46$

Campbell SJ, Miller CJ, Steven A, Stephens A (2003) Photosynthetic responses of two temperate seagrasses across a water quality gradient using chlorophyll fluorescence. J Exp Mar Biol Ecol 291:57-78

Dennison WC, Alberte RS (1985) Role of daily light period in the depth distribution of Zostera marina (eelgrass). Mar Ecol Prog Ser 25:51-61

Duarte CM, Sand-Jensen K (1990) Seagrass colonization: patch formation and patch growth in Cymodocea nodosa. Mar Ecol Prog Ser 65:193-200

Duarte CM, Marbà N, Agawin N, Cebrián J and 8 others (1994) Reconstruction of seagrass dynamics: age determinations and associated tools for the seagrass ecologist. Mar Ecol Prog Ser 107:195-209

Durako M (1994) Seagrass die-off in Florida bay (USA): changes in shoot demographic characteristics and population dynamics in Thalassia testudinum. Mar Ecol Prog Ser 110:59-66

EPA (1996) The Westernport marine environment. In: May D, Stephens A (eds) Report 493. Environment Protection Authority, Victoria, p 1-123

Erftemeijer PLA, Herman PMJ (1994) Seasonal changes in environmental variables, biomass, production and nutrient contents in 2 contrasting tropical intertidal seagrass beds in south Sulawesi, Indonesia. Oecologia 99:45-59

Guidetti P, Fabiano M (2000) The use of lepidochronology to assess the impact of terrigenous discharges on the primary leaf production of the Mediterranean seagrass Posidonia oceania. Mar Pollut Bull 40:449-453

Hall MO, Durako MJ, Fourqurean JW, Zieman JC (1999) Decadal changes in seagrass distribution and abundance in Florida Bay. Estuaries 22:445-459

Heck KL Jr, Wetstone GS (1977) Habitat complexity and invertebrate species richness and abundance in tropical seagrass meadows. J Biogeogr 4:135-142

Hemminga MA, Duarte CM (2000) Seagrass ecology. Cambridge University Press, Cambridge

Inglis GJ (2000) Variation in the recruitment behaviour of seagrass seeds: implications for population dynamics and resource management. Pac Conserv Biol 5:251-259

Kendrick GA, Aylward MJ, Hegge BJ, Cambridge ML, Hillman K, Wyllie A, Lord DA (2002) Changes in seagrass coverage in Cockburn Sound, Western Australia between 1967 and 1999. Aquat Bot 73:75-87

Les DH, Moody ML, Jacobs SW, Bayer RJ (2002) Systematics of seagrasses (Zosteraceae) in Australia and New Zealand. Syst Bot 27(3):468-484

Longmore A (1997) Analysis of water quality in Western Port, 1973-97 in relation to protection of beneficial uses. Internal Report No. 4. Marine and Freshwater Resources Institute, Queenscliff, p 1-58

Marbà N, Duarte CM (1998) Rhizome elongation and seagrass clonal growth. Mar Ecol Prog Ser 174:269-280

Marbà N, Walker DI (1999) Growth flowering, and population dynamics of temperate Western Australian seagrasses. Mar Ecol Prog Ser 184:105-118

Marbà N, Cerbrián J, Enríquez S, Duarte CM (1996) Growth patterns of Western Mediterranean seagrasses: species specific responses to seasonal forcing. Mar Ecol Prog Ser 133:203-215

Nakaoka M, Aioi K (1999) Growth of seagrass Halophila ovalis at dugong trails compared to existing within-patch variation in a Thailand intertidal flat. Mar Ecol Prog Ser 184:97-103.

Parsons TR, Maita Y, Lalli CM (1989) A manual of chemical and biological methods for seawater analysis. Pergamon Press, Oxford

Peterson BJ, Fourqurean JW (2001) Large-scale patterns in seagrass (Thalassia testinudum) demographics in south Florida. Limnol Oceanogr 46(5):1077-1090

Sargeant I (1977) A review of the extent and environmental effects of erosion in the Westernport catchment. Environmental studies series publication no. 174. Ministry for Conservation, Melbourne

Sfriso A, Ghetti PF (1998) Seasonal variation in biomass, morphometric variables and production of seagrass in the lagoon of Venice. Aquat Bot 61:207-223

Shapiro MA (1975) Westernport Bay environmental study 1973-1974. Ministry for Conservation, Melbourne

Shepherd SA, McComb AJ, Bulthuis DA, Neverrauskas V, Steffensen DA, West R (1989) Decline of seagrasses. In: Larkum, AWD, McComb AJ, Shepherd SA (eds) Biology of seagrasses - a treatise on the biology of seagrasses with special reference to the Australasian region. Elsevier, Amsterdam, p 346-387

Short FT, Wyllie-Echeverria S (1996) Natural and humaninduced disturbance of seagrasses. Environ Conserv 23: $17-27$

Tomasko DA, Hall MO (1999) Productivity and biomass of the seagrass Thalassia testinudum along a gradient of freshwater influence in Charlotte Harbor, Florida. Estuaries 22: 592-602

Vermaat JE, Agwin NSR, Duarte CM, Fortes MD, Marbà N, Uri JS (1996) Meadow maintenance, growth and productivity of a mixed Philippine seagrass bed. Mar Ecol Prog Ser 124:215-225

Virnstein RW (1995) Seagrass landscape diversity in the Indian River Lagoon, Florida: the importance of geographic scale and pattern. Bull Mar Sci 57(1):67-74

Zieman JC, Fourqurean JW, Frankovich TA (1999) Seagrass die-off in Florida Bay: long-term trends in abundance and growth of turtle grass, Thalassia testudinum. Estuaries 22: $460-470$

Submitted: January 26, 2004; Accepted: May 24, 2005

Proofs received from author(s): November 23, 2005 